\section{BIBLIO COUNS}

\title{
Studi Deskriptif tentang Pola Asuh Otoritatif, Kontrol Diri dan Sikap Remaja terhadap Perilaku Seks Bebas
}

\author{
Dwi Adhinda Junaidi Putri \\ Program Studi S2 Bimbingan dan Konseling, University Negeri Padang, Sumatera Barat, \\ Indonesia. Korespondensi: JI. Prof. Hamka, Padang. Email: adhindadwi@gmail.com
}

\author{
Article Info \\ History of Article \\ Submited June 2019 \\ Approved July 2019 \\ Published July 2019
}

\author{
Key Word \\ Authoritative Parenting, \\ Self Control, \\ Attitude, \\ Free Sex

\section{Kata Kunci} \\ Pola Asuh Otoritatif, \\ Kontrol Diri, \\ Sikap, \\ Seks Bebas
}

\begin{abstract}
Adolescent's attitude will affect the way they behave. Adolescent's attitude toward free sex is the degree to which the adolescent accept or refuse the various forms of sexual behavior carried out by a couple who are not bound in the bonds of marriage. Authoritative parenting and self-control is a factor that are factors that may have influenced the adolescent's attitude towards free sex. This study aimed to describe: (1) the level of applied authoritative parenting, (2) the level of adolescent's self-control, and (3) the level of adolescent's attitude towards free sex. This study used quantitative approach by using descriptive method. The population of this research were 303 students at SMAN 1 Stabat growing with authoritative parenting. By using proportional stratified random sampling technique, 172 students were chosen as the samples. The instrument of the research was a scale. The purpose of the research was analyzed by using hypothetic mean. The results of the research revealed that: (1) the authoritative parenting applied by parents was in fairly adequate category, (2) the adolescent's self-control was in adequate category, (3) the adolescent's attitude towards free sex was in reasonably refused category.
\end{abstract}

\begin{abstract}
Abstrak
Sikap remaja akan mempengaruhi cara mereka berperilaku. Sikap remaja terhadap seks bebas adalah sejauh mana remaja menerima atau menolak berbagai bentuk perilaku seksual yang dilakukan oleh pasangan yang tidak terikat dalam ikatan pernikahan. Pola asuh otoriter dan kontrol diri adalah faktor yang mungkin mempengaruhi sikap remaja terhadap seks bebas. Penelitian ini bertujuan untuk mendeskripsikan: (1) tingkat pengasuhan otoritatif yang diterapkan, (2) tingkat kontrol diri remaja, dan (3) tingkat sikap remaja terhadap seks bebas. Penelitian ini menggunakan pendekatan kuantitatif dengan menggunakan metode deskriptif. Populasi penelitian ini adalah 303 siswa di SMAN 1 Stabat yang tumbuh dengan pola asuh authoritative. Dengan menggunakan teknik proportional stratified random sampling, 172 siswa dipilih sebagai sampel. Instrumen penelitian adalah skala. Tujuan penelitian dianalisis dengan menggunakan mean hipotetik. Hasil penelitian menunjukkan bahwa: (1) pola asuh otoritatif yang diterapkan oleh orang tua dalam kategori cukup memadai, (2) kontrol diri remaja berada dalam kategori cukup, (3) sikap remaja terhadap seks bebas adalah dalam kategori cukup ditolak.
\end{abstract}

\section{Citation Info}

Putri, D.A.J. (2019). Studi Deskriptif tentang Pola Asuh Otoritatif, Kontrol Diri dan Sikap Remaja Terhadap Perilaku Seks Bebas. In Biblio Couns: Jurnal Kajian Konseling dan Pendidikan, 2(02), 78-88. 


\section{PENDAHULUAN}

Layanan Bimbingan dan Konseling (BK) merupakan salah satu bagian dari pendidikan yang bertujuan untuk membantu siswa agar berkembang secara optimal. Pencapaian tujuan pendidikan yang sukses akan membentuk remaja yang mempunyai karakter yang baik, sehingga akan membuat remaja terhindar dari berbagai macam bentuk masalah yang sering dialami remaja. Masalah yang sering dihadapi remaja sering diberhubungan dengan kenakalan remaja yang juga merupakan masalah sosial.

Lickona (2013) mengatakan bahwa remaja marak terlibat masalah perilaku seks bebas. Perilaku seks bebas dimaknai sebagai suatu perilaku seksual yang dilakukan oleh laki-laki dan perempuan tanpa ikatan resmi pernikahan yang memiliki dampak negatif baik secara psikis, sosial, dan akademis bagi remaja yang melakukannya. Perilaku seks bebas ini merupakan dampak nyata dari perkembangan zaman, arus globalisasi, dan pesatnya kemajuan teknologi terhadap kehidupan remaja. Dampak yang paling nyata adalah terbentuknya sikap baru tentang perilaku seksual remaja.

Penyebaran informasi yang sedemikian cepat, ditambah dengan tuntutan tugas perkembangan yang dipengaruhi oleh faktor biologis pada diri remaja dan rasa keingintahuan remaja yang besar tentang perilaku seksual, sering mengakibatkan remaja mengalami perubahan pola pikir dan cara pandang terhadap perilaku seksual yang akan bermuara pada terbentuknya pola sikap yang salah dan akhirnya menyebabkan perilaku seks bebas.

Sikap remaja terhadap perilaku seks bebas akan menunjukkan kecenderungan remaja untuk melakukan atau tidak melakukan perilaku seks bebas. Sikap remaja terhadap perilaku seks bebas dipengaruhi pengetahuan remaja terhadap perilaku seks bebas, keyakinan remaja terhadap perilaku seks bebas, dan bagaimana perilaku yang akan remaja lakukan terkait dengan pengetahuan dan keyakinannya terhadap perilaku seks bebas.

Penyebab perilaku seks bebas menurut Kartono (2005:196) karena, "Ketidakharmonisan dalam kehidupan psikis dari kehidupan keluarga". Pada masa remaja peran orangtua dan guru sangat berpengaruh untuk memberikan penjelasan tentang makna-makna seksualitas pada remaja yang sesuai dengan nilai-nilai yang berlaku di masyarakat. Lingkungan keluarga sebagai lingkungan pertama bagi remaja memegang peran dalam pembentukan sikap remaja terutama dalam masalah yang berkaitan dengan perilaku seks bebas. Nilai dan norma yang diajarkan orangtua sejak dini dapat menjadi pondasi bagi perkembangan remaja pada masa yang akan datang (Angelina \& Mutilessy, 2013).

Perilaku seks bebas adalah salah satu masalah perilaku yang berkaitan dengan nilai di masyarakat sosial. Kecenderungan seseorang untuk berperilaku dapat diprediksi melalui sikapnya terhadap objek sikap tersebut (dalam hal ini sikap remaja terhadap perilaku seks bebas). Sikap remaja terhadap perilaku seks bebas adalah bagaimana cara seseorang bersikap, baik berupa sikap positif atau sikap negatif terhadap perilaku seks bebas. Menurut teori pembelajaran sosial yang dikemukakan oleh Bandura (dalam Rahman, 2013) ada dua faktor penting yang mempengaruhi proses belajar perilaku sosial individu yaitu faktor kognitif dan sosial.

Faktor lingkungan dalam pembelajaran sosial dalam penelitian ini adalah lingkungan keluarga. Lingkungan keluarga lebih terfokus terhadap pola asuh yang diterapkan orangtua dalam mendidik anaknya. Pola asuh otoritatif yang diterapkan orangtua dalam mendidik anak akan membantu anak dalam memperoleh pengetahuan dan penanaman keyakinan akan suatu hal apakah hal itu baik/buruk atau sesuai/tidak sesuai dengan nilai moral masyarakat. 
Biblio Couns : Jurnal Kajian Konseling dan Pendidikan | Vol. 2 No. 2 Juli 2019

Faktor kognitif dalam penelitian ini adalah kontrol diri yang merupakan salah satu faktor yang mempengaruhi sikap remaja terhadap perilaku seks bebas. Calhoun \& Acocella (1990:130) mendefinisikan, "Kontrol diri sebagai pengaturan proses-proses fisik, psikologis, dan perilaku seseorang. Dengan kata lain serangkaian proses yang membentuk dirinya sendiri". Kontrol diri merupakan suatu kecakapan individu dalam kepekaan membaca situasi diri dan lingkungannya.

Synder dan Gangestad (dalam Ghufron \& Risnawita, 2014:22) menyatakan bahwa, "Konsep mengenai kontrol diri secara langsung sangat relevan untuk melihat hubungan antara individu dengan lingkungan masyarakat yang sesuai dengan isyarat situasional dalam bersikap dan berpendirian yang efektif". Individu dengan kontrol diri yang tinggi sangat memperhatikan cara-cara yang tepat untuk berperilaku dalam situasi yang bervariasi.

Individu yang mempunyai kontrol diri yang tinggi akan menghindari hal-hal yang hanya menimbulkan kesenangan sesaat. Remaja yang mempunyai kontrol diri yang tinggi akan menghindari perilaku yang tidak sesuai dengan tuntutan lingkungannya, dalam penelitian ini remaja yang mempunyai kontrol diri yang tinggi akan bersikap negatif atau menolak perilaku seks bebas yang bisa dijadikan sebagai salah satu prediktor bahwa remaja tersebut menolak untuk melakukan perilaku seks bebas.

Menurut Walgito (dalam Gufron, 2003) keluarga merupakan lingkungan yang pertama bagi anak, merupakan tempat yang sangat penting peletakan dasar dalam pembangunan mental dan pembentukan pribadi anak-anak. Hasil penelitian Lamborn dan Steinberg (dalam Desmita, 2009) menunjukkan bahwa perjuangan remaja untuk meraih otonomi tampaknya berhasil dengan sangat baik dalam lingkungan keluarga yang secara simultan memberikan dorongan dan kesempatan bagi remaja untuk memperoleh kebebasan emosional. Orangtua yang menerapkan pola asuh otoritatif akan secara terbuka dengan anak membicarakan segala hal yang terkait dengan perilaku seks. Sehingga anak akan mengetahui dampak perilaku seks terhadap perkembangan dan kehidupan remaja baik kehidupan pribadi maupun sosialnya.

Keluarga yang menerapkan pola asuh otoritatif menampilkan perilaku orangtua yang selalu memberikan penguatan terhadap perilaku baik yang dilakukan anak. Selain itu, orangtua juga dengan tegas membuat aturan-aturan yang harus dilakukan oleh anak, dimana dalam penyusunan dan pengambilan keputusan untuk aturan tersebut anak diikutsertakan dalam musyawarah keluarga. Sebagai lingkungan sosial yang paling dekat dengan remaja, keluarga menjadi tempat pertama bagi remaja untuk membentuk karakter agar mampu menentukan dan memilih perilaku atau tingkah laku yang akan dipilih dan diterapkan dalam lingkungan sosial yang lebih luas.

\section{METODOLOGI}

Jenis penelitian ini adalah penelitian kuantitatif dengan metode deskriptif; analisis data penelitian dilakukan dengan analisis mean hipotetic. Penelitian ini menunjukkan hal-hal sebagai berikut: (a) berikut: (a) pola asuh otoritatif (b) kontrol diri siswa (c) sikap remaja terhadap perilaku seks bebas.

Populasi dalam penelitian ini adalah 303 orang siswa, di SMA Negeri 1 Stabat Kabupaten Langkat, Provinsi Sumatera Utara Tahun Ajaran 2014/2016. Sampel diambil dengan cara proportional random sampling, sehingga didapat jumlah sampel sebanyak 172 siswa.

\section{HASIL PENELITIAN}

\section{Deskripsi Data Pola Asuh Otoritatif $\left(\mathrm{X}_{1}\right)$}

Secara keseluruhan jumlah item pernyataan variabel pola asuh otoritatif sebanyak 34 item, dengan rentangan skor dari 1 sampai 5, skor tertinggi 170, dan skor terendah 
Biblio Couns : Jurnal Kajian Konseling dan Pendidikan | Vol. 2 No. 2 Juli 2019 34. Kriteria pengkategorian instrumen pola asuh otoritatif menggunakan mean hipotetic yang dibagi menjadi lima kategori. Deskripsi rata-rata dan persentase skor hasil pengolahan data melalui instrumen pola asuh otoritatif dari keseluruhan sampel (responden) yang berjumlah 172 siswa berdasarkan masing-masing indikator, dapat dilihat pada Tabel 1.

Tabel 1. Deskripsi Rata-rata (Mean) dan Persentase (\%) Pola Asuh Otoritatif Berdasarkan Indikator

\begin{tabular}{|c|c|c|c|c|c|c|c|c|c|}
\hline \multirow[b]{2}{*}{ No } & \multirow[b]{2}{*}{ Indikator } & \multicolumn{8}{|c|}{ Skor } \\
\hline & & Ideal & Max & Min & $\Sigma$ & Mean & $\%$ & Sd & Ket \\
\hline 1 & $\begin{array}{l}\text { Orangtua menunjukkan perhatian } \\
\text { dan perasaan positif pada anak } \\
\text { (5). }\end{array}$ & 25 & 25 & 8 & 2847 & 16.55 & 66.2 & 4.002 & S \\
\hline 2 & $\begin{array}{l}\text { Orangtua menghargai dan } \\
\text { mendorong anak untuk } \\
\text { mengungkapkan pendapat (4). }\end{array}$ & 20 & 17 & 5 & 1950 & 11.34 & 56.7 & 3.268 & S \\
\hline 3 & $\begin{array}{l}\text { Orangtua mendengarkan keluhan } \\
\text { anak (4). }\end{array}$ & 20 & 19 & 5 & 1972 & 11.47 & 57.3 & 2.984 & S \\
\hline 4 & $\begin{array}{l}\text { Orangtua berkomunikasi dan } \\
\text { bersikap luwes dengan anak (4). }\end{array}$ & 20 & 16 & 5 & 1808 & 10.51 & 52.6 & 2.424 & $S$ \\
\hline 5 & $\begin{array}{l}\text { Orangtua menerapkan kendali } \\
\text { yang tegas atas perilaku anak } \\
\text { (5). }\end{array}$ & 25 & 23 & 6 & 2430 & 14.13 & 56.5 & 3.324 & S \\
\hline 6 & $\begin{array}{l}\text { Orangtua konsisten terhadap } \\
\text { peraturan yang dibuat }(3) \text {. }\end{array}$ & 15 & 15 & 3 & 1476 & 8.58 & 57.2 & 2.785 & S \\
\hline 7 & $\begin{array}{l}\text { Orangtua menekankan } \\
\text { kemandirian pada anak (3). }\end{array}$ & 15 & 15 & 4 & 1394 & 8.10 & 54.0 & 2.591 & S \\
\hline 8 & $\begin{array}{l}\text { Orangtua mendidik dengan cara } \\
\text { memberikan penjelasan yang } \\
\text { masuk akal (3). }\end{array}$ & 15 & 14 & 3 & 1640 & 9.53 & 63.6 & 2.621 & S \\
\hline 9 & $\begin{array}{l}\text { Orangtua memberi penghargaan } \\
\text { pada anak (3). }\end{array}$ & 15 & 15 & 4 & 1570 & 9.13 & 60.9 & 2.301 & S \\
\hline & Keseluruhan & 170 & 119 & 89 & 17376 & 101.023 & 59.40 & 6.158 & $\mathbf{S}$ \\
\hline eter & an: & & & & & & & & \\
\hline Sd & $\begin{array}{l}\text { : Skor Tertinggi yang diperoleh Sis } \\
\text { : Standar Deviasi } \\
\text { : Skor Tertinggi yang diperoleh Sis } \\
\text { : Sedang }\end{array}$ & & & & & & & & \\
\hline
\end{tabular}

Tabel 1 di atas memperlihatkan bahwa secara keseluruhan skor untuk masing-masing indikator berada pada kategori sedang (S). Tabel 1 di atas menunjukkan secara keseluruhan tingkat penerapan pola asuh otoritatif dengan skor ideal 170, skor tertinggi yang diperoleh siswa adalah 119 dan skor terendah yang diperoleh siswa adalah 89. Secara keseluruhan skor total yang diperoleh yaitu 17.376 dengan rata-rata skor yang diperoleh siswa yaitu 101,02 atau $59,4 \%$ dari skor ideal dengan standar deviasi sebesar 6,158. Dengan demikian secara rata-rata tingkat penerapan pola asuh otoritatif orangtua siswa berada pada kategori sedang. Kategori sedang dimaknai bahwa orangtua mengasuh dengan cara menerima anak, menggunakan kewenangan atas perilaku anak, dan melakukan bina kasih dengan anak, namun capaian pada kategori sedang menunjukkan bahwa orangtua belum melakukan halhal tersebut secara konsisten.

Tabel 1 memperlihatkan bahwa persentasi rata-rata capaian skor untuk indikator orangtua menunjukkan perhatian dan perasaan positif pada anak capaiannya paling tinggi diantara indikator lain yaitu sebesar $66,2 \%$, artinya anak berpersepsi bahwa orangtua sudah menunjukkan perhatian dan perasaan positif pada anak. Tabel 1 juga memperlihatkan bahwa persentasi rata-rata capaian skor terendah berada pada indikator orangtua berkomunikasi dan bersikap luwes dengan anak yaitu sebesar $52,6 \%$. Kesimpulan yang dapat diambil dari Tabel 1 adalah secara keseluruhan persentasi rata-rata capaian skor berada pada kategori sedang (S), namun untuk masing-masing indikator mempunyai rata-rata capaian skor yang berbeda meski tetap dalam satu kategori. 
Biblio Couns : Jurnal Kajian Konseling dan Pendidikan | Vol. 2 No. 2 Juli 2019

Jadi, secara rata-rata tingkat pola asuh otoritatif yang diterapkan orangtua siswa berada pada kategori sedang. Kategori sedang dimaknai bahwa orangtua mengasuh dengan cara menerima anak, menggunakan kewenangan atas perilaku anak, dan melakukan bina kasih dengan anak, namun capaian pada sedang baik menunjukkan bahwa orangtua belum melakukan hal-hal tersebut secara konsisten.

\section{Deskripsi Data Kontrol Diri $\left(\mathrm{X}_{2}\right)$}

Secara keseluruhan jumlah item pernyataan variabel kontrol diri sebanyak 34 item, dengan rentangan skor dari 1 sampai 5 , skor tertinggi 170 , dan skor terendah 34 . Kriteria pengkategorian instrumen kontrol diri menggunakan mean hipotetic yang dibagi menjadi lima. Deskripsi rata-rata dan persentase skor hasil pengolahan data melalui instrumen kontrol diri dari keseluruhan sampel (responden) yang berjumlah 172 siswa berdasarkan masing-masing indikator, dapat dilihat pada Tabel 2.

\section{Tabel 2. Deskripsi Rata-rata (Mean) dan Persentase (\%) Kontrol Diri Berdasarkan Indikator}

\begin{tabular}{|c|c|c|c|c|c|c|c|c|c|}
\hline \multirow[t]{2}{*}{ No } & \multirow[b]{2}{*}{ Indikator } & \multicolumn{8}{|c|}{ Skor } \\
\hline & & Ideal & Max & Min & $\Sigma$ & Mean & $\%$ & Sd & Ket \\
\hline 1. & $\begin{array}{l}\text { Mengontrol tindakan atas dasar inisiatif } \\
\text { sediri (7). }\end{array}$ & 35 & 34 & 15 & 4268 & 24.81 & 70.9 & 3.988 & $\mathrm{~T}$ \\
\hline 2. & $\begin{array}{l}\text { Membuat prioritas kegiatan yang akan } \\
\text { dilakukan (6). }\end{array}$ & 30 & 27 & 8 & 3238 & $\begin{array}{c}18.82 \\
6\end{array}$ & 62.8 & 3.928 & $\mathrm{~S}$ \\
\hline 3 & $\begin{array}{l}\text { Mampu mengendalikan keadaan/situasi } \\
\text { (4). }\end{array}$ & 20 & 20 & 5 & 2118 & $\begin{array}{c}12.31 \\
4\end{array}$ & 61.6 & 2.551 & $S$ \\
\hline 4 & $\begin{array}{l}\text { Melakukan pertimbangan sebelum } \\
\text { bertindak (4). }\end{array}$ & 20 & 19 & 5 & 1928 & $\begin{array}{c}11.20 \\
9\end{array}$ & 56.0 & 2.433 & $S$ \\
\hline 5 & $\begin{array}{l}\text { Menilai keadaan lingkungan dengan baik } \\
\text { (5). }\end{array}$ & 25 & 25 & 7 & 2978 & $\begin{array}{c}17.31 \\
4 \\
\end{array}$ & 69.3 & 3.419 & $\mathrm{~T}$ \\
\hline 6 & $\begin{array}{l}\text { Melakukan antisipasi terhadap stimulus } \\
\text { yang tidak diharapkan (4). }\end{array}$ & 20 & 18 & 5 & 2161 & $\begin{array}{c}12.56 \\
4\end{array}$ & 62.8 & 2.310 & $S$ \\
\hline 7 & $\begin{array}{l}\text { Mengambil keputusan dengan } \\
\text { menggunakan berbagai pertimbangan } \\
\text { (4). }\end{array}$ & 20 & 19 & 4 & 2273 & $\begin{array}{c}13.21 \\
5\end{array}$ & 66.1 & 2.444 & $S$ \\
\hline & Keseluruhan & 170 & 142 & 87 & 18964 & $\begin{array}{c}110.2 \\
6\end{array}$ & 64.9 & $\begin{array}{c}12.71 \\
8\end{array}$ & $S$ \\
\hline
\end{tabular}

Keterangan:

Max : Skor Teringgi yang diperoleh Siswa

Min : : Skor Terendah yang diperoleh Siswa

Sd : : Standar Deviasi

T : : Tinggi

S : : Sedang

Tabel 2 memperlihatkan secara keseluruhan kontrol diri siswa dengan skor ideal 170, skor tertinggi yang diperoleh siswa adalah 142 dan skor terendah yang diperoleh siswa adalah 87. Secara keseluruhan skor total yang diperoleh yaitu 18.964 dengan rata-rata skor yang diperoleh siswa yaitu 110,26 atau 64,9\% dari skor ideal dengan standar deviasi sebesar 12,718. Dengan demikian secara rata-rata tingkat kontrol siswa berada pada kategori sedang (S). Kategori sedang untuk deskripsi data kontrol diri dimaknai bahwa siswa sudah mampu melakukan kontrol diri dengan cukup baik dalam kehidupan sehari-harinya dengan menguasai aspek-aspek kontrol diri yang dapat dilihat dari capaian rata-rata untuk masing-masing butir pernyataan instrumen penelitian.

Tabel 2 di atas memperlihatkan bahwa skor untuk indikator mengontrol tindakan atas dasar inisiatif sendiri dan menilai keadaan lingkungan dengan baik berada pada kategori tinggi. Berdasarkan indikator tersebut, kategori tinggi dimaknai bahwa siswa sudah mampu mengontrol perilaku yang dilakukan tanpa perlu dikontrol oleh orang lain.

Selanjutnya, capaian skor untuk indikator membuat prioritas kegiatan yang akan dilakukan, mampu mengendalikan keadaan/stimulus, melakukan pertimbangan sebelum bertindak, melakukan antisipasi terhadap stimulus yang tidak diharapkan, dan mengambil keputusan dengan menggunakan berbagai pertimbangan berada pada kategori Sedang (S). Secara umum dapat dimaknai meskipun siswa sudah mampu melakukan kontrol diri, namun untuk beberapa hal siswa belum mampu mengontrol dirinya, terutama untuk mengontrol 
Biblio Couns : Jurnal Kajian Konseling dan Pendidikan | Vol. 2 No. 2 Juli 2019 emosinya. Hal ini dapat dilihat pada inidikator melakukan pertimbangan sebelum bertindak dan indikator mampu mengendalikan keadaan/situasi yang skor capaiannya sebesar $56,0 \%$ dan $61,6 \%$.

Jadi, secara rata-rata tingkat kontrol diri siswa berada pada sedang. Kategori sedang dimaknai bahwa siswa sudah mampu melakukan kontrol diri dengan cukup baik dalam kehidupan sehari-harinya dengan menguasai aspek-aspek kontrol diri, namun siswa belum sepenuhnya mampu menguasai emosinya.

\section{Deskripsi Data Sikap Remaja terhadap Perilaku Seks Bebas (Y)}

Secara keseluruhan jumlah item pernyataan variabel sikap remaja terhadap perilaku seks bebas sebanyak 22 item, dengan rentangan skor dari 1 sampai 5, skor ideal 110, dan skor terendah 22. Kriteria pengkategorian instrumen sikap remaja terhadap perilaku seks bebas menggunakan mean hipotetic dan dibagi menjadi lima kategori. Deskripsi rata-rata dan persentase skor hasil pengolahan data melalui instrumen sikap remaja terhadap perilaku seks bebas dari keseluruhan sampel (responden) yang berjumlah 172 siswa berdasarkan masingmasing indikator, dapat dilihat pada Tabel 3.

Tabel 3. Deskripsi Rata-rata (Mean) dan Persentase (\%) Sikap Remaja terhadap Perilaku Seks Bebas (Y) Berdasarkan Indikator

\begin{tabular}{|c|c|c|c|c|c|c|c|c|c|}
\hline \multirow[t]{2}{*}{ No. } & \multirow{2}{*}{ Indikator } & \multicolumn{8}{|c|}{ Skor } \\
\hline & & Ideal & Max & Min & $\boldsymbol{\Sigma}$ & Mean & $\%$ & Sd & Ket \\
\hline 1 & $\begin{array}{l}\text { Pengetahuan tentang perilaku seks bebas } \\
\text { (5). }\end{array}$ & 25 & 25 & 8 & 3084 & 17.93 & $71.7 \%$ & 3.808 & M \\
\hline 2 & $\begin{array}{l}\text { Pandangan mengenai perilaku seks bebas } \\
\text { (6). }\end{array}$ & 30 & 27 & 10 & 3177 & 18.471 & $61.6 \%$ & 4.127 & CM \\
\hline 3 & $\begin{array}{l}\text { Perasaan terhadap perilaku seks bebas } \\
\text { (3). }\end{array}$ & 15 & 15 & 3 & 1480 & 8.6047 & $57.4 \%$ & 2.526 & $\mathrm{CM}$ \\
\hline 4 & $\begin{array}{l}\text { Kecenderungan melakukan perilaku seks } \\
\text { bebas (4). }\end{array}$ & 20 & 18 & 5 & 2021 & 11.75 & $58.8 \%$ & 2.476 & CM \\
\hline 5 & $\begin{array}{l}\text { Pandangan remaja terhadap kehidupan } \\
\text { bersama masyarakat yang berkaitan } \\
\text { dengan perilaku seks bebas (4). }\end{array}$ & 20 & 18 & 4 & 2051 & 11.924 & $59.6 \%$ & 2.843 & $\mathrm{CM}$ \\
\hline & Keseluruhan & 110 & 89 & 48 & 11813 & 68.68 & $62.4 \%$ & 7.246 & CM \\
\hline Keter & gan: & & & & & & & & \\
\hline $\begin{array}{l}\text { Max } \\
\text { Min } \\
\text { Sd } \\
\text { M } \\
\text { CM }\end{array}$ & $\begin{array}{l}\text { : Skor Teringgi yang diperoleh Siswa } \\
\text { : Skor Terendah yang diperoleh Siswa } \\
\text { : Standar Deviasi } \\
\text { : Menolak } \\
\text { : Cukup Menolak }\end{array}$ & & & & & & & & \\
\hline
\end{tabular}

Tabel 3 memperlihatkan bahwa untuk indikator pengetahuan tentang perilaku seks bebas berada pada kategori menolak (M), sedangkan capaian skor untuk indikator pandangan mengenai perilaku seks bebas, perasaan terhadap perilaku seks bebas, kecenderungan melakukan perilaku seks bebas, dan pandangan remaja terhadap kehidupan bersama masyarakat yang berkaitan dengan perilaku seks bebas berada pada kategori cukup menolak, artinya tingkatan kemenolakan siswa terhadap perilaku seks bebas berada pada tingkat sedang.

Tabel 3 secara keseluruhan memperlihatkan sikap siswa terhadap perilaku seks bebas dengan skor ideal 110, skor tertinggi yang diperoleh siswa adalah 89 dan skor terendah yang diperoleh siswa adalah 48. Secara keseluruhan skor total yang diperoleh yaitu 11.813 dengan rata-rata skor yang diperoleh siswa yaitu 68,68 atau $62,4 \%$ dari skor ideal dengan standar deviasi sebesar 7,246. Dengan demikian, secara rata-rata sikap remaja terhadap perilaku seks bebas berada pada kategori cukup menolak (berada pada tingkat sedang). Kategori cukup menolak pada deskripsi data dapat diartikan bahwa remaja cenderung cukup menolak butir pernyataan instrumen yang sifatnya mendukung perilaku seks bebas dan setuju dengan butir pernyataan instrumen yang menolak perilaku seks bebas, dimana tingkat kemenolakan ditinjau dari seluruh indikator sikap remaja terhadap perilaku seks bebas berada paa tingkat sedang. 
Biblio Couns : Jurnal Kajian Konseling dan Pendidikan | Vol. 2 No. 2 Juli 2019

Jadi, secara rata-rata sikap remaja terhadap perilaku seks bebas berada pada kategori kurang setuju. Kategori cukup menolak dimaknai bahwa siswa sudah mempunyai pengetahuan yang baik sehingga menolak bentuk-bentuk perilaku seks bebas yang bersifat ekstrem (hubungan intim), sedangkan untuk bentuk perilaku seks bebas seperti berpegangan tangan, berpelukan/berangkulan dengan lawan jenis, dan berciuman remaja cenderung menyetujuinya. Hingga dapat dikatakan tingkat kemenolakan remaja terhadap perilaku seks bebas berada pada tingkat sedang.

\section{PEMBAHASAN}

Pada bagian berikut akan dijelaskan pembahasan untuk masing- masing variabel sebagai berikut:

\section{Pola Asuh Otoritatif}

Hasil penelitian menunjukkan bahwa secara rata-rata tingkat penerapan pola asuh otoritatif berdasarkan persepsi anak berada pada kategori sedang. Muslich (2014:101) menyatakan bahwa, "Keberhasilan keluarga dalam menanamkan nilai-nilai kebajikan (karakter) pada anak sangat tergantung pada jenis pola asuh yang diterapkan orangtua pada anaknya". Melalui pola asuh yang diterapkan oleh orangtua, anak belajar tentang banyak hal termasuk belajar tentang karakter.

Sikap terhadap perilaku seks bebas merupakan salah satu hasil belajar dari pendidikan karakter yang diberikan orangtua kepada anak melalui penerapan pola asuh di dalam keluarga. Hasil analisis deskriptif data menunjukkan seluruh indikator berada pada kategori sedang. Kategori sedang dimaknai bahwa orangtua mengasuh dengan cara menunjukkan perilaku penerimaan pada anak, menggunakan kewenangan atas perilaku anak, dan melakukan bina kasih dengan anak, namun capaian pada kategori sedang menunjukkan bahwa orangtua belum melakukan hal-hal tersebut secara konsisten. Wujud kurang konsistennya orangtua dalam menerapkan pola asuh otoritatif adalah dengan adanya persepsi siswa yang merasa orangtua masih belum membuat siswa merasa nyaman untuk berkomunikasi dengan orangtua.

Kategori sedang pada deskrispsi data menunjukkan perlunya peningkatan pola asuh otoritatif, mengingat pentingnya penerapan pola asuh otoritatif dalam pembentukan karakter anak. Sejalan dengan pendapat Santrock (2007:16) yang menyatakan, bahwa "Pola asuh otoritatif diperkirakan merupakan pola asuh yang paling efektif dalam perkembangan karakter anak". Selanjutnya Steinberg \& Silk (dalam Santrock, 2007:16) yang menyatakan, "Secara umum, para peneliti telah menemukan bahwa pengasuh orangtua yang bersifat otoritatif berkaitan dengan aspek-aspek dari perkembangan". Jadi, dengan kata lain orangtua yang menerima anak atau memberi kasih sayang pada anak, baik secara verbal (diberikan katakata cinta dan kasih sayang, kata-kata yang membesarkan hati, dan dorongan), maupun secara fisik (diberi ciuman, elusan di kepala, pelukan, dan kontak mata yang hangat) akan membentuk karakter anak yang baik. Hal ini dikuatkan dengan hasil penelitian Rohner (dalam Muslich, 2014) yang menunjukkan bahwa pengalaman masa kecil seseorang sangat mempengaruhi perkembangan kepribadiannya (karakter atau kecerdasan emosinya). Oleh sebab itu, anak penting untuk mempunyai hubungan yang dekat dengan orangtua yang bisa didapat anak melalui penerimaan orangtua terhadap anak.

Lickona (2013) menyatakan berdasarkan indikasi penelitian yang dilakukannya, orangtua yang otoritatif adalah orangtua yang membimbing anak-anak untuk patuh pada orangtua, tapi juga memberi alasan yang jelas mengenai apa yang orangtua inginkan dari anak sehingga anak dapat meresapi logika dari sikap dan perilaku yang dilakukannya serta mampu melakukan tindakan yang bertanggung jawab atas inisiatif anak sendiri. Pola asuh otoritatif menggunakan komunikasi dua arah, dimana kedudukan antara orangtua dan anak dalam berkomunikasi sejajar. Artinya, apa yang dilakukan anak tetap harus ada di bawah pengawasan orangtua dan dapat dipertanggungjawabkan secara moral.

Berdasarkan hasil temuan penelitian dan pembahasan di atas diketahui bahwa jenis pola asuh yang diterapkan orangtua kepada anaknya sangat mementukan keberhasilan pendidikan karakter anak. Kesalahan dalam pengasuhan anak akan berakibat pada kegagalan dalam pembentukan karakter yang baik, termasuk pembentukan sikap yang salah. 
Biblio Couns : Jurnal Kajian Konseling dan Pendidikan | Vol. 2 No. 2 Juli 2019

Selain keluarga dan orangtua sekolah juga mempunyai peranan penting dalam proses pendidikan karakter anak. Sekolah seharusnya menekankan dan memperkuat nilai-nilai yang sudah baik yang ada pada anak yang merupakan hasil belajar anak dari orangtua.

Guru BK/konselor melalui penyelenggaraan berbagai jenis layanan dan kegiatan pendukung harusnya membantu siswa agar berkembang secara optimal. Melalui pelayanan $\mathrm{BK}$, guru BK/konselor sebagai pelaksana layanan harus mampu menjalin hubungan dan kerja sama yang baik dengan orangtua untuk bisa secara optimal mencapai tujuan pendidikan secara utuh untuk remaja. Lickona (2013:15) menyatakan, "Pencapaian tujuan pendidikan yang sukses akan membentuk remaja yang mempunyai karakter yang baik, sehingga membuat remaja terhindar dari berbagai macam bentuk masalah yang kerap kali dialami remaja".

\section{Kontrol Diri}

Hasil penelitian menunjukkan bahwa secara rata-rata tingkat kontrol diri siswa berada pada kategori sedang, artinya siswa sudah mampu mengontrol dirinya untuk melakukan perilaku atas dasar inisiatifnya sendiri, mampu menilai keadaan dengan baik, dan mampu untuk membuat keputusan. Namun, hasil deskripsi data menunjukkan bahwa siswa belum mampu mengontrol emosinya, contohnya siswa masih merasa cemas/takut bila membayangkan suatu hal buruk yang akan dihadapinya. Hal ini sejalan dengan penyataan Hurlock (dalam Khairunnisa, 2013) yang mengatakan kontrol diri berkaitan dengan bagaimana individu mengendalikan emosi serta dorongan-dorongan dalam dirinya. Ketidakmampuan siswa mengontrol emosinya menyebabkan tingkat kontrol diri siswa berkurang.

Kontrol diri diperlukan individu guna membantu individu dalam mengatasi berbagai hal merugikan yang berasal dari luar dirinya. Dikaitkan dengan hasil penelitian yang menyatakan tingkat kontrol diri siswa berada dalam kategori sedang berarti siswa sudah cukup mampu untuk mengarahkan dirinya pada perilaku-perilaku yang baik. Pada masa remaja terjadi banyak perubahan pada diri remaja yang dipengaruhi berbagai faktor yang akhirnya bermuara pada pembentukan sikap dan perilaku remaja. Oleh sebab itu, sangat perlu untuk remaja untuk membangun kontrol diri yang tinggi agar mampu mengarahkan dan mengatur perilakunya pada bentuk-bentuk perilaku yang positif. Calhoun \& Acocella (1990:126) menyatakan bahwa:

"Semakin tinggi tingkat kontrol diri individu berarti akan semakin baik individu tersebut dalam memandu, mengarahkan, dan mengatur perilakunya untuk tidak melakukan perilaku yang negatif. Sebaliknya semakin rendah kontrol diri individu maka semakin tidak mampu individu tersebut untuk memandu, mengarahkan, dan mengatur perilakunya untuk melakukan perilaku yang positif. "

Berdasarkan pada hasil penelitian capaian tingkat kontrol diri siswa sudah cukup baik. Keadaan seperti ini harus tetap dikembangkan, agar siswa lebih mampu dalam memandu, mengarahkan, dan mengatur sikap dan perilakunya kearah yang positif. Baiknya kontrol diri juga membantu remaja dalam mencapai tugas perkembangannya. Hasil penelitian ini diharapkan dapat membantu guru BK/konselor dalam membuat data analisis kebutuhan mengenai tingkat kontrol diri siswa. Selanjutnya data analisis kebutuhan yang akan dijadikan dasar penyusunan program pelayanan BK di sekolah. Melalui penyusunan program yang sesuai dengan analisis kebutuhan siswa, guru BK/konselor diharapkan dapat tetap mengembangkan dan meningkatkan kontrol diri siswa. Secara nyata diharapkan guru BK/konselor dapat memfokuskan pada bidang pengembangan pribadi. Salah satu cara yang tepat untuk diberikan guru BK/konselor adalah berbagai jenis layanan dengan materi yang tepat dan didukung dengan penyelenggaraan kegiatan pendukung BK lainnya dalam rangka meningkatkan dan mengembangkan kontrol diri siswa.

\section{Sikap Remaja terhadap Perilaku Seks Bebas}

Hasil penelitian menunjukkan bahwa secara rata-rata sikap siswa (selanjutnya disebut remaja) terhadap perilaku seks bebas berada dalam kategori cukup menolak. Kategori cukup menolak pada deskripsi data dapat diartikan bahwa sikap remaja cenderung cukup menolak 
Biblio Couns : Jurnal Kajian Konseling dan Pendidikan | Vol. 2 No. 2 Juli 2019

perilaku seks bebas. Capaian skor untuk indikator pengetahuan tentang perilaku seks bebas berada pada kategori menolak, yang artinya siswa mempunyai pengetahuan baik yang sifatnya menolak bentuk perilaku seks bebas. Dengan memiliki pengetahuan yang menolak terhadap perilaku seks bebas, maka wajar hasil penelitian menunjukkan bahwa remaja mempunyai sikap yang cukup menolak terhadap perilaku seks bebas.

Remaja menyetujui bahwa dorongan seksual yang muncul dari dalam diri untuk melakukan perilaku seksual harus dikendalikan, wujud cinta yang dalam tulus tidak perlu dilakukan dengan melakukan perilaku seks bebas, dan melakukan perilaku seks bebas berarti merusak nama baik keluarga (butir pernyataan nomor 1, 2, 4, 6 7, dan 8 pada skala sikap remaja terhadap perilaku seks bebas). Hasil penelitian juga menunjukkan bahwa remaja mempunyai padangan bahwa bentuk perilaku berpegangan tangan, berangkulan/berpelukan, dan bentuk perilaku seks bebas lainnya kecuali hubungan intim (hubungan suami istri) tidak termasuk sebagai bentuk perilaku seks bebas. Dengan pengetahuan yang dimiliki remaja ini, maka remaja akan berkecenderungan mempunyai sikap menolak terhadap perilaku seks bebas.

Capaian skor untuk indikator pandangan remaja terhadap perilaku seks bebas berada pada kategori cukup menolak, hasil penelitian memperlihatkan bahwa remaja memandang bentuk perilaku seks bebas yang mengakibatkan terjadinya pernikahan dini atau hilangnya keperawanan/keperjakaan dengan pandangan menolak, yang artinya akan membuat siswa berkecenderungan untuk tidak melakukan perilaku tersebut. Namun, hasil penelitian juga menunjukkan bahwa remaja memandang bentuk-bentuk perilaku seks bebas yang masih berada pada batas aturan dan norma yang ada (seperti berpegangan tangan, berpelukan, dan/atau bentuk kontak fisik lainnya dengan pasangan) dengan pandangan yang kurang menolak, dengan kata lain remaja berkecenderungan untuk mendukung bentuk perilaku tersebut. Hal ini yang membuat sikap remaja menjadi cukup menolak terhadap perilaku seks bebas.

Hasil deskripsi data juga menunjukkan bahwa capaian skor untuk indikator perasaan terhadap perilaku seks bebas yang merupakan bagian dari sub variabel afektif sikap remaja terhadap perilaku seks bebas juga berada pada kategori cukup menolak. Kategori cukup menolak pada indikator ini dimaknai bahwa remaja merasa tidak suka bila ada orang lain yang mengolok-ngolok temannya karena membuat batasan-batasan untuk tidak melakukan kontak fisik dalam bergaul dengan lawan jenis, namun remaja mempunyai perasaan yang suka terhadap bentuk perilaku seperti bergandengan/berpelukan dengan lawan jenis yang juga termasuk dalam bentuk perilaku seks bebas.

Selanjutnya capaian untuk indikator pada sub variabel konatif sikap remaja terhadap perilaku seks bebas, yang tediri dari indikator kecenderungan melakukan perilaku seks bebas dan pandangan remaja terhadap kehidupan bersama masyarakat yang berkaitan dengan perilaku seks bebas juga masih berada pada kategori cukup menolak. Kategori untuk capaian pada kedua indikator ini dapat dimaknai bahwa siswa menyetujui bentuk-bentuk perilaku perilaku seks bebas yang masih berada pada batas aturan dan norma yang ada (seperti berpegangan tangan, berpelukan, dan/atau bentuk kontak fisik lainnya dengan pasangan) sehingga berkecenderungan untuk melakukan perilaku tersebut. Capaian skor juga menunjukkan bahwa siswa menyetujui bahwa melakukan bentuk perilaku seks bebas (yang sudah melanggar norma seperti hubungan intim) merupakan suatu hal yang dapat merusak nama baik keluarga, namun remaja menyetujui bahwa bentuk-bentuk perilaku seks bebas (pasangan yang belum menikah tinggal bersama dan hubungan intim) boleh dilakukan oleh pasangan-pasangan yang akan menikah dan bila kedua pihak tidak merasa terpaksa/suka sama suka. Kategori cukup menolak ini juga dimaknai bahwa remaja tidak menyetujui untuk melakukan bentuk perilaku seks bebas, namun siswa tidak memandang bahwa orang lain juga tidak harus melakukan bentuk perilaku tersebut (cenderung membiarkan orang lain berperilaku seks bebas).

Pembentukan sikap remaja terhadap perilaku seks bebas yang merupakan salah satu sikap sosial terjadi karena adanya interaksi sosial yang dialami oleh remaja. Azwar menyatakan (2011) interaksi sosial membuat remaja bereaksi membentuk pola sikap tertentu terhadap perilaku seks bebas, diantara berbagai faktor yang mempengaruhi pembentukan sikap adalah pengalaman pribadi, kebudayaan, orang lain yang dianggap penting, media massa, instansi/lembaga pendidikan dan lembaga agama, serta faktor emosi remaja sendiri. 
Biblio Couns : Jurnal Kajian Konseling dan Pendidikan | Vol. 2 No. 2 Juli 2019 Fishbein \& Ajzen (1975:35) menyatakan, "Attitude is a multidimensional construct comprising cognitive, affective, and conative. Although all these components are in an evaluative kuntinum but each statement can be different'. Yang dimaknai bahwa sikap merupakan suatu konstrak multidimensional yang terdiri atas aspek kognitif, afektif, dan konatif. Meskipun kesemua komponen berada pada suatu kuntinum evaluatif akan tetapi pernyataan masingmasing dapat berbeda.

Pendapat di atas sejalan dengan fenomena di lapangan dan hasil penelitian yang dilakukan. Sikap yang merupakan suatu proses evaluatif menyebabkan sikap siswa terhadap perilaku seks bebas cenderung berbeda untuk masing-masing aspek pembentuk sikap, namun akan tetap menunjukkan sebuah kecenderungan untuk menyikapi perilaku seks bebas ini, baik pada kecenderungan menerima atau menolak perilaku seks bebas.

Hasil penelitian menunjukkan sikap remaja terhadap perilaku seks bebas berkecenderungan menolak perilaku seks bebas. Kecenderungan ini muncul karena dipengaruhi oleh pengetahuan dan padangan remaja terhadap perilaku seks bebas. Remaja yang berpandangan bahwa bentuk perilaku berangkulan/bergandengan, berpelukan hingga berciuman bukan merupakan bentuk perilaku seks bebas, maka akan berkecenderungan menyetujui perilaku seks bebas (mempunyai sikap menerima terhadap perilaku seks bebas) dan akan berkencenderungan untuk melakukan perilaku-perilaku tersebut dan sebaliknya. Pada masa remaja dorongan seksual yang muncul wajar karena terjadi perkembangan yang optimal pada organ-organ seks yang menyebabkan munculnya dorongan seksual pada diri remaja. Adanya dorongan seksual ini yang akhirnya mendorong remaja melakukan perilaku tersebut.

Azwar (2011) menyatakan sikap yang merupakan suatu respon evaluatif hanya akan timbul karena didasari oleh proses evaluasi dalam diri individu yang memberi stimulus yang akan membentuk kesimpulan terhadap objek sikap (perilaku seks bebas) dalam bentuk nilai baik/buruk, menerima/menolak, menyenangkan/tidak menyenangkan, yang kemudian mengkristal sebagai potensi terhadap objek sikap. Selanjutnya Azwar (2011) mengatakan sikap juga dipengaruhi oleh pengalaman di masa lalu dan harapan individu di masa yang akan datang. Oleh sebab itu, wajar bila hasil penelitian menunjukkan bahwa remaja cenderung mempunyai sikap yang cukup menolak terhadap bentuk perilaku seks bebas yang dilakukan oleh orang lain (butir pernyataan pada indikator pandangan remaja terhadap kehidupan bersama dengan masyarakat yang berkaitan dengan perilaku seks bebas).

Faktor lain yang mempengaruhi sikap adalah pengaruh orang yang dianggap penting, lembaga pendidikan, dan media massa. Pada masa remaja, remaja akan lebih banyak menghabiskan waktu bersama dengan kelompok sosial di luar lingkungan keluarga. Selain itu, perkembangan teknologi dan arus globalisasi menyebabkan terbentuknya cara pandang dan pola sikap baru pada remaja. Pola sikap kelompok sosial juga akan mempengaruhi pola sikap remaja sebagai anggota kelompok. Artinya, bila kelompok mempunyai sikap yang cenderung menolak terhadap perilaku seks bebas, maka individu juga akan mempunyai pola sikap yang cenderung mengikuti pola sikap kelompoknya.

Sikap remaja terhadap perilaku seks bebas bukan suatu hal yang muncul begitu saja dalam diri siswa. Berdasarkan hasil penelitian ini Guru BK/Konselor sebagai bagian dari lembaga pendidikan yang juga mempengaruhi pembentukan sikap remaja, memiliki peranan penting untuk mengembangkan sikap menolak terhadap perilaku seks bebas. Oleh sebab itu guru BK/konselor, mempunyai peran dalam pembentukan sikap remaja terhadap perilaku seks bebas agar terbentuk sikap menolak terhadap perilaku seks bebas.

Rahman (2013) mengatakan bahwa sikap terbentuk karena proses belajar, salah satunya sikap terbentuk karena reward-punishment. Guru BK/konselor bisa memberikan reward untuk sikap siswa yang benar, dan sebaliknya memberi punishment untuk sikap siswa yang salah. Pembentukan dan perubahan bentuk sikap dapat terjadi karena proses asosiasi (learning through association: classical conditioning), dimana individu mempunyai kecenderungan sikap tertentu pada suatu objek kadang terjadi karena asosiasi antara informasi baru dengan informasi yang sudah diketahui (Rahman, 2013). Usaha membentuk sikap remaja terhadap perilaku seks bebas yang dapat dilakukan guru BK/konselor adalah dengan menyelenggarakan berbagai jenis layanan dan kegiatan pendukung diantaranya penyelenggaraan layanan informasi dan layanan bimbingan kelompok. Penyelenggaraan jenis layanan tersebut juga memerlukan pelaksanaan kegiatan pendukung dengan harapan 
Biblio Couns : Jurnal Kajian Konseling dan Pendidikan | Vol. 2 No. 2 Juli 2019 tercapainya tujuan pelayanan BK secara optimal di sekolah, dalam hal ini terbentuknya sikap menolak terhadap perilaku seks bebas.

\section{KESIMPULAN} ini.

Berdasarkan hasil dan pembahasan penelitian, dapat disimpulkan hal-hal sebagai berikut

1. Secara rata-rata gambaran pola asuh otoritatif yang diterapkan orangtua siswa berada pada kategori sedang.

2. Secara rata-rata tingkat kontrol diri siswa berada pada kategori sedang.

3. Secara rata-rata sikap siswa terhadap perilaku seks bebas terdapat pada kategori cukup menolak yang artinya tingkat kemenolakan remaja terhadap perilaku seks bebas berada pada tingkat sedang.

\section{REFERENSI}

Angelina, D.Y., \& Mutilessy, A. 2013. "Pola Asuh Otoriter, Kontrol Diri, dan Perilaku Seks Bebas Remaja SMK". Jurnal Psikologi Indonesia, 2 (2): 173-182.

Azwar, S. 2011. Sikap Manusia Teori dan Pengukurannya. Yogyakarta: Pustaka Pelajar.

Badan Pusat Statistik, Badan Kependudukan dan Keluarga Berencana Nasional, \& Kementerian Kesehatan. 2013. Survei Demografi dan Kesehatan Indonesia (SDKI) 2012. (Online), (www.academia.edu, diakses April 2014).

Calhoun, J.F., \& Acocella, J.R. Tanpa tahun. Psikologi Tentang Penyesuaian dan Hubungan Kemanusiaan Edisi Ketiga. Terjemahan oleh R.S. Satmoko. 1990. Semarang: IKIP Semarang Press.

Dariyo. 2004. Psikologi Perkembangan Remaja. Jakarta: Ghalia Indonesia.

Ghufron, M.N. 2003. "Hubungan Kontrol Diri dan Persepsi Remaja Terhadap Penerapan Disiplin Orangtua Terhadap Prokrasinasi Akademik". Tesis tidak diterbitkan. Yogyakarta: Fakultas Psikologi Universitas Gajah Mada.

Ghufron, M.N., \& Risnawita, R. 2014. Teori-teori Psikologi. Yogyakarta: Ar-Ruzz Media.

Kartono, K. 2005. Patologi Sosial 2 Kenakalan Remaja. Jakarta: Raja Grafindo Persada.

Khairunnisa, A. 2013. Hubungan Religiulitas dan Kontrol Diri dengan Perilaku Seksual Pranikah Remaja di MAN 1 Samarinda. Ejournal Psikologi, 2013, 1 (2): 220-229.

Lickona, T. Tanpa tahun. Mendidik untuk Membentuk Karakter: Bagaimana sekolah dapat memberikan pendidikan tentang sikap hormat dan bertanggung jawab. Terjemahan oleh Juma Abdu Wamaungo. 2013. Jakarta: Bumi Akasara.

Muslich. M. 2014. Pendidikan Karakter: Menjawab tantangan krisis multidimensional. Jakarta: Bumi Aksara.

Santrock, J.W. Tanpa tahun. Remaja Edisi 11 Jilid 1. Terjemahan oleh Benedictine Widyasinta. 2007. Jakarta: Erlangga.

Santrock, J.W. Tanpa tahun. Remaja Edisi 11 Jilid 2. Terjemahan oleh Benedictine Widyasinta. 2007. Jakarta: Erlangga. 